\title{
ORIGINAL
}

ARTICLES

\section{The Current State of Research Capacity in US Family Medicine Departments}

Amanda Weidner, MPH; Lars E. Peterson, MD, PhD; Arch G. Mainous, III, PhD; Avisek Datta, MSIBS; Bernard Ewigman, MD, MSPH

BACKGROUND AND OBJECTIVES: Capacity for conducting family medicine research has grown significantly since the specialty was founded. Many calls to increase this capacity have been published, but there has been no consistent, systematic, and longitudinal assessment. This survey was designed to gather baseline data with an easily replicable set of measures associated with research productivity that can guide and monitor the impact of efforts to build research capacity in US departments of family medicine (DFMs).

METHODS: We surveyed family medicine department chairs regarding departmental research capacity using well-established empirical measures of capacity (trained research faculty, infrastructure, research leadership, and funding) and a self-assessment. We used bivariate analyses to assess correlation between the empirical measures and the self-assessed stage of research capacity.

RESULTS: Self-assessed capacity was significantly associated with every empirical measure. High-capacity departments have more research-trained faculty, more faculty effort, utilize more research "laboratories," have more faculty serving on federal peer-review panels, more faculty as principal investigators, devote more internal funding to research, and garner larger amounts of funding from more external funding sources than moderate or minimal-capacity departments.

CONCLUSIONS: US DFMs have made great strides over the past half century in building research capacity. However, much more capacity in family medicine and primary care research is needed to produce new knowledge necessary to improve the health and health care of the nation. Periodic measurement using the simple, replicable, and valid minimum measures of this study provides an opportunity to establish longitudinal tracking of change in research capacity in US DFMs.

(Fam Med. 2019;51(2):112-119.)

doi: 10.22454/FamMed.2019.180310

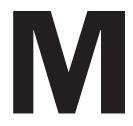

edical specialties are characterized by a definable body of medical knowledge applicable to patient care, and a scientific foundation with active investigation and new knowledge generation. ${ }^{1}$ Family medicine has defined an emerging body of knowledge, has quintessential applicability to patient care, and research been measured only sporadically and inconsistently. Past work has documented definite strides forward but also often noted that the family medicine research enterprise falls short of what is needed to address intractable problems and optimally improve the health of the nation., ${ }^{2,9,10}$ While studies have reported on individual faculty productivity, ${ }^{11,12}$ residency program productivity, ${ }^{13-16}$ numbers of publications, ${ }^{17-24}$ amount of funding from national sources, ${ }^{25-28}$ publication quality, ${ }^{29}$ and research infrastructure and barriers to productivity ${ }^{30}$ the family medicine department research landscape has not been systematically assessed using a consistent conceptual framework. 6,10 The growth in capacity for research in family medicine is therefore difficult to describe as a longitudinal enterprise.

To better understand the current state and to establish a baseline from which to monitor future growth

From the Association of Departments of Family Medicine, Leawood, KS (Ms Weidner); University of Washington Department of Family Medicine (Ms Weidner); American Board of Family Medicine, Lexington, KY (Dr Peterson); Department of Family and Community Medicine, University of Kentucky, Lexington, KY (Dr Peterson); Department of Community Health and Family Medicine and Department of Health Services Research, Management and Policy University of Florida, Gainesville, FL (Dr Mainous III); NorthShore University HealthSystem, Evanston, IL (Mr Datta and Dr Ewigman); and Department of Family Medicine, University of Chicago (Dr Ewigman). 
of research capacity in family medicine departments, Family Medicine for America's Health (FMAHealth), the Association of Departments of Family Medicine (ADFM), and the Council of Academic Family Medicine (CAFM) Educational Research Alliance (CERA) collaborated to develop a survey tool in 2016, guided by the Bland model ${ }^{29,30}$ to measure research capacity in family medicine departments in the United States. We describe the findings of this survey in this report.

A guiding goal of this survey was to generate a minimum set of well-established research capacity measures associated with research productivity from an easily replicated and reliable data source. Our expectation is that establishing a baseline of measures will provide a beginning to guide current efforts to build research capacity, in particular the Building Research Capacity (BRC) initiative, ${ }^{5}$ and create an opportunity to track long-term trends.

\section{Methods}

ADFM has defined core characteristics that meaningfully reflect departmental research capacity. We have operationalized those characteristics using measures that would generate some of the minimum data needed to mark meaningful progress over time. ADFM (authors A.W. and B.E.), FMAHealth Research Tactic Team (L.P.), and CERA (A.M.) investigators developed survey items on research capacity, attitudes toward research, and barriers and facilitators of research success at the department and institution level. The findings from these latter measures will be reported in a subsequent document.

\section{Study Population and Data Collection}

Surveys were sent by email to chairs of family medicine departments who were members of ADFM in September 2016 using the standard CERA survey methodology. ${ }^{31} \mathrm{ADFM}$ includes virtually all allopathic departments, many regional branch campuses, several osteopathic departments, and several departments in large regional medical centers that have research and medical education missions. Respondents were instructed to complete all data with reference to the 2015 calendar or 2015 fiscal year only. During the study period, nonresponders received four reminder messages. The survey was closed in November 2016.

The Institutional Review Board of the American Academy of Family Physicians approved this study.

\section{Instrumentation}

The survey included questions about the chair, department, and institutional background and demographics. Survey items were constructed to empirically measure variables from four general categories known to characterize research-productive departments in the Bland model. ${ }^{32,33}$ The four categories selected for this study were: Trained research faculty: (1) number of individual faculty with dedicated research effort, and (2) number of full-time equivalents (FTE) of faculty dedicated to research. Infrastructure: (3) number of research laboratories providing sources of data for faculty investigators, and (4) types of research laboratories providing sources of data (primary or secondary). Research leadership: (5) department faculty roles as principal investigators on active grants and contracts, and (6) number of faculty who currently serve on federal research peer-review panels. Funding: (7) proportion of FTEs of research faculty externally funded for salary support; (8) amount of internal/in-kind department research funding; (9) number of external awards (grants, contracts, philanthropy); (10) sources of external awards; and (11) amounts of external awards. Variable definitions are available upon request.

Each chair was also asked to designate one of five stages of research capacity of their department: none, minimal, moderate, significant, or extensive, based on their own assessment (self-assessed capacity). These designations were subsequently collapsed to minimal, moderate, and high capacity for the analyses.

Analyses were completed using SPSS 19.0.0 and SAS 9.3. Categorical variables were compared via the $\chi^{2}$ test. Continuous variables were compared across groups via Student $t$ test or analysis of variance (ANOVA) as appropriate, except where data were not normally distributed. In these cases, a nonparametric Kruskal-Wallis test was employed. Categorical variables were collapsed into fewer values where necessary to have adequate cell counts for statistical analysis, or where data revealed that combining values would be more informative.

\section{Results}

\section{Department and Chair \\ Characteristics}

A total of 109 of 142 invited departments completed the survey (77\% response rate). The majority of responding departments were located on the main campuses of allopathic medical schools $(74 \%)$ and were public institutions (63\%; Table 1). The oldest was founded in 1964 and the youngest in 2013 , with a median of 39.0 years (interquartile range or IQR=19.5 years) since the year of founding as of 2015. Data were missing on year of founding for 16 departments (15\%). The mean number of total doctoral-level (MD, DO, $\mathrm{PhD}, \mathrm{EdD}$, etc) faculty reported per department was $41.0(\mathrm{SD}=45.3)$, among whom there was a mean of 32.4 FTE (SD=32.4).

Thirty-six $(33 \%)$ of the department chairs had been serving for less than 3 years, 30 (28\%) for 3-10 years, and $32(29 \%)$ for more than 10 years. Thirty (28\%) self-identified as researchers for "most or all" of their career before becoming a chair, though 41 (38\%) never identified as a researcher and many had less than $10 \%$ personal effort (FTE) for research and scholarship prior to becoming a chair (39\%; Table 1). 
Table 1: Responding Department and Chair Characteristics

\begin{tabular}{|c|c|c|}
\hline & Response Option & $\mathbf{N}(\%)^{*}$ \\
\hline \multirow{6}{*}{ Department setting } & Allopathic medical school-main site & $81(74)$ \\
\hline & Allopathic medical school-branch campus & $11(10)$ \\
\hline & Osteopathic medical school & $0(0)$ \\
\hline & Regional medical center & $4(4)$ \\
\hline & Other & $3(3)$ \\
\hline & No response & $10(9)$ \\
\hline \multirow{3}{*}{ Public or private institution } & Public & $69(63)$ \\
\hline & Private & $30(28)$ \\
\hline & No response & $10(9)$ \\
\hline \multirow{5}{*}{$\begin{array}{l}\text { Students matriculating at your } \\
\text { school of medicine }\end{array}$} & $<75$ & $13(12)$ \\
\hline & $75-149$ & $34(31)$ \\
\hline & $>149$ & $48(44)$ \\
\hline & NA & $4(4)$ \\
\hline & No response & $10(9)$ \\
\hline \multirow{4}{*}{$\begin{array}{l}\text { How long have you been chair of } \\
\text { your current department? }\end{array}$} & $<3$ years & $36(33)$ \\
\hline & $3-10$ years & $30(28)$ \\
\hline & $>10$ years & $32(29)$ \\
\hline & No response & $11(10)$ \\
\hline \multirow{6}{*}{$\begin{array}{l}\text { Personal effort (FTE) for research } \\
\text { and scholarship }{ }^{1} \text { in your academic } \\
\text { career prior to becoming a } \\
\text { department chair }\end{array}$} & 0 or minimal effort & $6(6)$ \\
\hline & $<10 \%$ effort & $37(34)$ \\
\hline & $10 \%-30 \%$ effort & $27(25)$ \\
\hline & $30 \%-60 \%$ effort & $22(20)$ \\
\hline & $>60 \%$ effort & $8(7)$ \\
\hline & No response & $9(8)$ \\
\hline \multirow{5}{*}{$\begin{array}{l}\text { Identify self as researcher }{ }^{2} \text { prior to } \\
\text { becoming chair }\end{array}$} & During my entire career without exceptions & $12(11)$ \\
\hline & During most of my career & $18(17)$ \\
\hline & During some of my career & $30(28)$ \\
\hline & Never & $41(38)$ \\
\hline & No response & $8(7)$ \\
\hline
\end{tabular}

* Percentage values have been rounded to the nearest whole number.

${ }^{1}$ Research and scholarship are broadly defined vs clinical practice/teaching/administration/other.

${ }^{2}$ Functioned and identified yourself as a researcher with a significant track record of external funding and peer-reviewed original research publications.

\section{Self-assessed Research Capacity}

Forty-eight (44\%) respondents reported having none or minimal research in their department (minimal capacity); 23 (21\%) considered their department research capacity as moderate (moderate capacity), and $38(34 \%)$ considered their departmental research as significant or extensive (high capacity). All of the 38 self-assessed high-capacity departments were on the main campus of allopathic medical schools. There was no difference in research capacity stage between departments in public versus private medical schools. High-capacity departments tended to be slightly older (median $=41.5$ years, IQR $=12.3$ years) than moderate-capacity (median $=37.0$ years, $\mathrm{IQR}=31.0$ years) or minimal-capacity (median $=40.0$ years, $\mathrm{IQR}=15.5$ years) departments $(P=.042)$.
Association of Empirical

Measures of Capacity With

Self-assessed Capacity

Trained Research Faculty. Highcapacity departments were far more likely to have five or more individual research faculty (87\%) and more than four FTE faculty time devoted to research $(82 \%)$ than either minimal capacity or moderate capacity departments $(P<.001$; Table 2$)$. 
Infrastructure. High-capacity departments were more likely to use more than one primary research laboratory (74\%), including practice-based research networks (PBRN), local practices, community-based surveys, or other primary data sources $(P=.024)$. High-capacity departments were also much more likely to use multiple secondary research laboratories (63\%), including clinical data networks, enterpriselevel data warehouses, large secondary databases, or existing narrative data than departments with either minimal or moderate-capacity departments $(P<.001)$. Almost half of departments indicated that they used a PBRN as a research laboratory (48\%), though minimal capacity departments trended toward being more likely to use a PBRN (65\% vs $44 \%$ for moderate and $42 \%$ for highcapacity departments, $P=.074$ ).

Research Leadership. Slightly less than half of the departments (45\%) reported one or more faculty who had served on a federal peer-review panel for research or research training proposals in 2015. Seventy-nine percent of high-capacity departments had at least one faculty serve on a federal grant review panel in $2015(P<.001$; Table 2$)$. Department faculty served as the principal investigator (PI) on two-thirds of reported sources of funding for all departments in 2015. High-capacity departments were significantly more likely to report having more than two award sources for which the PI was in their department (87\%) than minimal or moderate-capacity departments $(P<.001$; Table 2$)$. The mean award sources with a PI from the department reported for high-capacity departments was $3.7(\mathrm{SD}=2.2)$ compared to $2.0(\mathrm{SD}=1.2)$ for moderate-capacity departments and 0.75 $(\mathrm{SD}=1.0)$ for minimal-capacity departments $(P<.001)$.

Table 2: Characteristics of Research Productive Departments According to Self-Assessed Stage of Research Capacity

\begin{tabular}{|c|c|c|c|c|c|c|}
\hline & & & Self- & essed Stag & Research Capa & \\
\hline Charac & teristics of Research-Producti & Departments & $\begin{array}{l}\text { Minimal } \\
\text { Capacity }\end{array}$ & $\begin{array}{l}\text { Moderate } \\
\text { Capacity }\end{array}$ & High Capacity & D Valun \\
\hline & & & & & & \\
\hline Total & & & $48(44)$ & $23(21)$ & $38(34)$ & \\
\hline & Doctoral-level research & $\begin{array}{l}4 \text { individuals or } \\
\text { fewer }\end{array}$ & $42(88)$ & $14(61)$ & $5(13)$ & 0001 \\
\hline Trained & faculty & $\begin{array}{l}5 \text { or more } \\
\text { individuals }\end{array}$ & $6(13)$ & $9(39)$ & $33(87)$ & $<.001$ \\
\hline & Doctoral-level research & 4 FTE or less & $32(67)$ & $19(83)$ & $6(16)$ & 001 \\
\hline & $\mathrm{FTE}^{1}$ & $>4 \mathrm{FTE}$ & $3(6)$ & $3(13)$ & $31(82)$ & $<.001$ \\
\hline & Use primary research & Use 0 or 1 labs & $21(44)$ & $3(13)$ & $10(26)$ & 000 \\
\hline & laboratories $^{2}$ & Use $>1$ labs & $27(56)$ & $20(87)$ & $28(74)$ & .024 \\
\hline Intrastructure & Use secondary research & Use 0 or 1 source & $39(81)$ & $16(70)$ & $14(37)$ & $<.001$ \\
\hline & & Use $>1$ labs & $9(19)$ & $7(30)$ & $24(63)$ & \\
\hline & Department faculty & None & $37(77)$ & $14(26)$ & $4(11)$ & \\
\hline Research & federal peer-review panels & At least 1 & $10(21)$ & $9(18)$ & $30(79)$ & $<.001$ \\
\hline & Number of award sources & 1 or fewer & $39(81)$ & $9(39)$ & $5(13)$ & 001 \\
\hline & with PI in department & 2 or more & 9 (19) & $14(61)$ & $33(87)$ & $<.001$ \\
\hline & Fyternal salary sumnort & $0 \%-50 \%$ & $31(65)$ & $16(70)$ & $13(34)$ & \\
\hline & for research $\mathrm{FTE}^{1}$ & $>50 \%$ & $4(8)$ & $6(26)$ & $24(63)$ & $<.001$ \\
\hline Funding & Total direct dollar or in- & $<\$ 100,000$ & $41(85)$ & $11(48)$ & $6(16)$ & \\
\hline & to research support ${ }^{1}$ & $\$ 100,000$ or more & $6(13)$ & $12(52)$ & $28(74)$ & 001 \\
\hline
\end{tabular}

${ }^{1}$ Percentages do not add up to 100 in all cells due to missing values.

${ }^{2}$ Practice-based research networks; local clinical practice sites; community-based surveys; primary data collection of any type (quantitative or qualitative).

${ }^{3}$ Clinical data networks; enterprise-level data warehouses; large secondary quantitative databases; existing narrative data. 


\section{Funding}

High-capacity departments were far more likely to have more than $50 \%$ external funding for salary recovery of research faculty time devoted to research $(63 \%, P<.001)$. In addition, the majority of high-capacity departments invested more than $\$ 100,000$ of internal/in-kind department support for research in 2015 (Table 2). Approximately one-third ( $\mathrm{N}=11)$ of the high-capacity departments provided more than $\$ 300,000$ of internal/in-kind support.

Of the 109 responding departments, $89(82 \%)$ reported that at least one department faculty member had externally-funded research effort. Among those with funding, the National Institutes of Health (NIH) was the single most common source of funding, followed by other federal and foundation funding (Table 3). Industry accounts for a very small percentage of department funding sources. Of note, most funding sources provided a relatively small amount of support directly to the department (less than $\$ 100,000$ for the year). The federal government accounted for the great majority of large ( $\$ 100,000$ to $\$ 500,000$ annual direct support to the department) and very large awards (more than $\$ 500,000$ annual direct support; Table 4). Including awards for which the principal investigator was outside of the family medicine department, high-capacity departments had a mean of 4.4 external award sources, including an average of two to three large or very large award sources providing annual direct costs to the department. In contrast, minimal-capacity departments had an average just over one award per department, almost all of which were small (Figure 1).

As described above, self-assessed stage of research capacity was strongly associated with every empirical measure of research capacity (see below, Tables $2-4$, and Figure 1) including those reflecting research-trained faculty, infrastructure (research laboratories), research leadership, and funding.

\section{Discussion}

In this national survey, roughly onethird of family medicine departments reported empirical measures of research capacity known to be predictive of research productivity and were classified by their chairs as having high capacity for research. These departments have developed a research-trained faculty, utilized numerous research "laboratories" and data sets, devoted more faculty effort and internal funding to research, and garner more funding from more award sources, particularly federal sources, than the remaining twothirds of departments. This represents progress from prior estimates of research capacity across the discipline of family medicine. Although it is not possible from this data to establish the growth of research capacity precisely over time, there can be no question that family medicine research capacity has developed meaningfully since the recognition as a specialty 50 years ago and the opening of new departments of family medicine that followed.

The need for research training in family medicine has been well described in the literature, and numerous initiatives and programs have been developed to address major gaps that still exist. ${ }^{34-38}$ Our results are consistent with Bland's findings that there is a "critical mass" of research faculty and research FTE

Table 3: Research Funding Sources: Number of Departments With Funding From Source and Count of Grants or Contracts by Source

\begin{tabular}{|c|c|c|c|c|c|c|}
\hline \multirow[b]{2}{*}{ Source } & \multirow{2}{*}{$\begin{array}{l}\text { Number of Departments } \\
\text { With Any Grants or } \\
\text { Contracts According } \\
\text { to Source (\% of Total) }\end{array}$} & \multirow{2}{*}{$\begin{array}{l}\text { Total Number } \\
\text { of Award Grant } \\
\text { or Contract } \\
\text { Sources (\%) }\end{array}$} & \multicolumn{4}{|c|}{$\begin{array}{l}\text { Number of Award Grant or Contract Sources } \\
\text { According to Annual Funding Amount (in 2015) }\end{array}$} \\
\hline & & & $\begin{array}{c}\text { Small } \\
<\$ 100 K\end{array}$ & $\begin{array}{c}\text { Large } \\
\$ 100 K- \\
<\$ 500 K\end{array}$ & $\begin{array}{l}\text { Very Large } \\
>\$ 500 \mathrm{~K}\end{array}$ & $\begin{array}{l}\text { Amount Not } \\
\text { Specified }\end{array}$ \\
\hline $\mathrm{NIH}^{1}$ & $50(56)$ & $94(28)$ & 40 & 31 & 13 & 10 \\
\hline Other federal ${ }^{1,2}$ & $54(61)$ & $69(21)$ & 31 & 21 & 9 & 8 \\
\hline Foundations $^{1}$ & $42(47)$ & $55(17)$ & 23 & 12 & 6 & 14 \\
\hline AHRQ & $33(37)$ & $33(10)$ & 13 & 9 & 5 & 6 \\
\hline PCORI & $30(34)$ & $30(9)$ & 12 & 10 & 4 & 4 \\
\hline State agencies & $28(32)$ & $28(9)$ & 8 & 7 & 9 & 4 \\
\hline Industry & $16(18)$ & $16(5)$ & 10 & 4 & 0 & 2 \\
\hline Other $^{3}$ & $6(7)$ & $6(2)$ & 4 & 1 & 0 & 1 \\
\hline Total & $89(100)$ & $331(100)$ & $141(43 \%)$ & $95(29 \%)$ & $46(14 \%)$ & $49(15 \%)$ \\
\hline
\end{tabular}

${ }^{1}$ Several departments had multiple grants or contracts from the National Institutes of Health, National Science Foundation, and/or private foundations.

${ }^{2}$ National Science Foundation, Centers for Disease Control, Center for Medicare and Medicaid Services, Veterans Administration, Department of Defense, and other.

${ }^{3}$ Other not specified. 
Table 4: NIH, Other Federal, and Nonfederal Award Sources by Self-assessed Stage of Research Capacity

\begin{tabular}{|c|c|c|c|c|c|}
\hline Source & & $\begin{array}{c}\text { Minimal } \\
\text { Capacity (\%) }\end{array}$ & $\begin{array}{c}\text { Moderate } \\
\text { Capacity (\%) }\end{array}$ & High Capacity (\%) & $P$ Value \\
\hline \multirow{2}{*}{$\mathrm{NIH}^{1}$} & Any & 9 (19) & $10(44)$ & $31(82)$ & \multirow{2}{*}{$<.001$} \\
\hline & None & $39(81)$ & $13(57)$ & $7(18)$ & \\
\hline \multirow{2}{*}{ Non-NIH federal entities ${ }^{2}$} & Any & $18(38)$ & $15(65)$ & $35(92)$ & \multirow{2}{*}{$<.001$} \\
\hline & None & $30(63)$ & $8(35)$ & $3(8)$ & \\
\hline \multirow{2}{*}{ Nonfederal entities ${ }^{3}$} & Any & $21(44)$ & $16(70)$ & $28(74)$ & \multirow{2}{*}{.011} \\
\hline & None & $27(56)$ & $7(30)$ & $10(26)$ & \\
\hline
\end{tabular}

${ }^{1}$ Several departments had multiple grants or contracts from the National Institutes of Health (NIH).

${ }^{2}$ PCORI, AHRQ, National Science Foundation, Centers for Disease Control, Center for Medicare and Medicaid Services, Veterans Administration, Department of Defense, and other not specified.

${ }^{3}$ State, private foundations, industry, other not specified.

Figure 1: Self-assessed Stage of Research Capacity by Mean Number of Award Sources per Department Categorized by Size of Direct Amount of Award to the Department

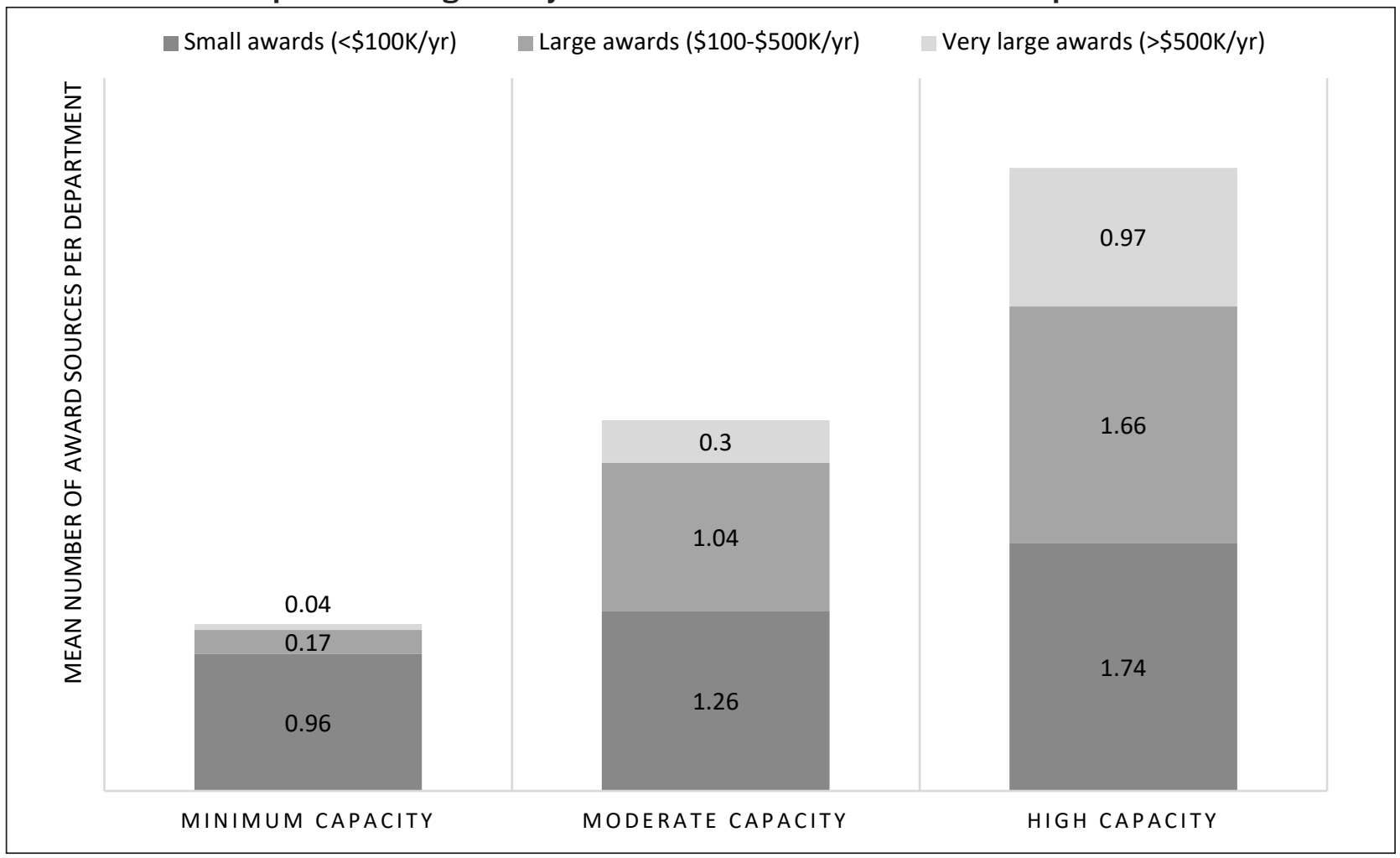

associated with research capacity. Other findings that support these associations included the presence of researchers within the department with the capacity to function as leaders of research teams in the role of principal investigator, as well as having nationally recognized faculty to serve on federal review panels for research or research training proposals.
Utilizing a wide range of research laboratory types-both primary and secondary-was also associated with departments with high research capacity in this study. Notably, secondary sources of data were less commonly used in lower-capacity departments despite being more readily available and often free or low cost. For departments looking to grow their capacity, the use of secondary data sources should be considered as a lower-cost way to boost productivity. PBRNs are widely utilized by departments of all capacity levels, offer an excellent option for the generation of new knowledge, and are likely among the best settings for asking and answering primary care questions. However, simply having a PBRN as a 
laboratory does not lead directly to a high-capacity research enterprise.

Compared to other specialties, family medicine receives very little funding from the National Institutes of Health (NIH). ${ }^{25-28,39-42}$ That said, funding from the NIH is the primary source of financing for family medicine research, though funding from other federal sources such as the Agency for Healthcare Research and Policy (AHRQ), the Patient Centered Outcomes Research Institute (PCORI), the National Science Foundation (NSF), the Centers for Disease Control and Prevention (CDC), and the Centers for Medicare and Medicaid Services (CMS), as well as funding from private foundations, is also crucial. Detrimental to family medicine research has been the dramatic decline in funding from the Health Resources and Services Administration (HRSA), whose Title VII mechanism was previously used to support research, research training, and research faculty development in the past several decades. ${ }^{43}$

This study provides a snapshot of research capacity via a sample with a robust response rate and delivers more targeted and distinct measures of research capacity in family medicine. One of our primary goals was to compare well-established empirical measures of research capacity with a measure of self-assessed research capacity. We found that the 11 empirical variables were highly and consistently associated with the self-assessed classifications. The selfassessment question can therefore be considered to have sufficient face validity to be used as a single-item tool going forward. However, even the 11 variables used as empirical measures of research capacity do not generate an excessive response burden, as was demonstrated by the $77 \%$ response rate. This study provides a beginning for reporting a minimum set of metrics that can be tracked longitudinally through periodic survey of departments of family medicine. For example, the self-assessed measure could be used more frequently, perhaps every 3 years, whereas the empirical measures could be used less frequently, such as every 5 to 10 years. Research capacity generally changes very slowly (either increasing or declining) or not at all for most departments in the span of 3 to 5 years.

A limitation of this study is that not much is known about the nonresponding departments, including departments in osteopathic medical schools, of which very few were ADFM members at the time of the survey. Our sample excludes residency programs ${ }^{13-16}$ with faculty not employed in academic departments as well as family medicine researchers based in research institutes, research centers, and research agencies outside of departments of family medicine. Therefore, some research capacity in the specialty has likely gone unmeasured in this survey. However, the majority of family medicine research is generated from academic departments of family medicine. ${ }^{19}$

As a trade-off for creating a survey that was brief and straightforward to answer, and given that this work was being done in tandem with other efforts to measure research publication productivity, we did not report on publications or other scholarly outputs. In addition, our methodology lacks the detail and depth of more intensive studies of productivity. ${ }^{11,17-21,29}$ There is also an enormous amount of scholarly activity not reflected by grants and high-impact peer-reviewed original research publications. Measurement of the scholarly activity of departments and residency programs broadly conceptualized would be an important complement to the current study.

Many family medicine departments, if not most, rightly prioritize clinical service, residency training and medical student education and devote precious resources to these mission-critical areas. Some departments are sponsored by institutions that either do not aspire to have a research culture or have not been successful in creating one. These departments may not identify externally-funded original research as a core mission, may lack the necessary leadership experience, or simply have not had the resources to feasibly increase their capacity for research. Additionally, trying to make all departments similar given their diverse structures and missions is not a good use of resources, nor does it recognize the strengths and contributions of departments that focus primarily on patient care, education and training, and community service. However, many departments with limited research capacity do aspire to grow their capacity. This study provides more context for these departments and the initiatives designed to facilitate the development of research resources for the discipline. Future evaluation will help track growth going forward and future research should examine the different perspectives, missions, and goals of departments and residency programs within the context of research as well as capacity and productivity for scholarly activity defined more broadly. ${ }^{44}$

The implications of these findings with respect to strategic approaches to building research capacity are beyond the scope of this study. However, it should be clear that new chairs (or existing chairs) charged with building research capacity would be well advised to negotiate a robust financial package to make the investments necessary to achieve these well established empirical elements.

In summary, the research capacity of family medicine departments in the United States has progressed substantially since their founding in the past 5 decades, though research capacity in family medicine departments is modest among all disciplines. There is a substantial unmet need for sources of funding for training family medicine researchers and supporting their research agendas. This survey was undertaken to establish a baseline from which to guide current efforts such as the Building Research Capacity initiative $^{6}$ and determine the impact on increasing future research capacity 
more broadly in departments that have the desire, leadership, and resources to grow.

ACKNOWLEDGMENTS: Some data from this study were presented at the 2018 North American Primary Care Research Group Annual Conference in Chicago, November 9-13, 2018.

CORRESPONDING AUTHOR: Address correspondence to Bernard Ewigman, MD, Department of Family Medicine, The University of Chicago, 5841 S Maryland Ave, Rm M-156, MC7110, Chicago, IL 60637. 773-834-9852. Fax: 773-834-9864. bewigman@uchicago.edu. bewigman@northshore.org.

\section{References}

1. Cassel CK, Reuben DB. Specialization, subspecialization, and subsubspecialization in internal medicine. N Engl J Med. 2011;364(12):1169-1173.

2. Bowman MA, Lucan SC, Rosenthal TC, Mainous AG III, James PA. Family Medicine Research in the United States From the late 1960s Into the Future. Fam Med. 2017;49(4):289-295.

3. Parkerson GR Jr, Barr DM, Bass M, et al. Meeting the challenge of research in family medicine: report of The Study Group on Family Medicine Research. J Fam Pract. 1982;14(1):105-113.

4. Scherger JE, Young HF. The AAFP research initiative. J Fam Pract. 1998;46(3):203-204.

5. North American Primary Care Research Group Committee on Building Research Capacity; Academic Family Medicine Organizations Research Subcommittee. What does it mean to build research capacity? Fam Med. 2002;34(9):678-684.

6. Ewigman B, Davis A, Vansaghi T, et al. Building research and scholarship capacity in departments of family medicine: a new joint ADFM-NAPCRG initiative. Ann Fam Med. 2016;14(1):82-83.

7. van Weel C, Rosser WW. Improving health care globally: a critical review of the necessity of family medicine research and recommendations to build research capacity. Ann Fam Med. 2004;2(suppl 2):S5-S16.

8. Jaén CR, Borkan J, Newton W; Association of Departments of Family Medicine. The next step in building family medicine research capacity: finding the way from fellowship. Ann Fam Med. 2006;4(4):373-374.

9. deGruy FV III, Ewigman B, DeVoe JE, et al. A Plan for Useful and Timely Family Medicine and Primary Care Research. Fam Med. 2015;47(8):636-642.

10. James P, Davis A, Borkan J; Association of Departments of Family Medicine. The challenge to build research capacity in family medicine: is our discipline ready? Ann Fam Med. 2010;8(4):371-373

11. Brocato JJ, Mavis B. The research productivity of faculty in family medicine departments at U.S. medical schools: a national study. Acad Med. 2005;80(3):244-252.
12. Ferrer RL, Katerndahl DA. Predictors of shortterm and long-term scholarly activity by academic faculty: a departmental case study. Fam Med. 2002;34(6):455-461.

13. Crawford P, Seehusen D. Scholarly activity in family medicine residency programs: a national survey. Fam Med. 2011;43(5):311-317.

14. Kruse JE, Bradley J, Wesley RM, Markwell SJ. Research support infrastructure and productivity in U.S. family practice residency programs. Acad Med. 2003;78(1):54-60.

15. Mills OF, Zyzanski SJ, Flocke S. Factors associated with research productivity in family practice residencies. Fam Med. 1995;27(3):188193.

16. Young RA, Dehaven MJ, Passmore C, Baumer JG. Research participation, protected time, and research output by family physicians in family medicine residencies. Fam Med. 2006;38(5):341-348.

17. Weiss BD. Publications by family medicine faculty in the biomedical literature: 1989-1999. Fam Med. 2002;34(1):10-16.

18. Pathman DE, Gamble G, Thaker S, Newton WP. A metric of progress for family medicine research: from the North American Primary Care Research Group. Ann Fam Med. 2005;3(1):88-89.

19. Pathman DE, Viera AJ, Newton WP. Research published in 2003 by U.S. family medicine authors. J Am Board Fam Med. 2008;21(1):6-16.

20. Wagner PJ, Hornsby JL, Talbert FS, Hobbs J, Brown GE, Kenrick J. Publication productivity in academic family medicine departments. Fam Med. 1994;26(6):366-369.

21. Merenstein J, Rao G, Wolfe S, Weaver-Agostoni J. Clinical research in family medicine: published articles 2000 and 2005. Fam Med. 2009;41(1):7-8.

22. Clenney T, Viera A. Debating the current status of research in family medicine. Fam Med. 2002;34(7):493.

23. Jelercic S, Lingard H, Spiegel W, Pichlhöfer O, Maier M. Assessment of publication output in the field of general practice and family medicine and by general practitioners and general practice institutions. Fam Pract. 2010;27(5):582-589.

24. Pols DHJ, Bramer WM, Bindels PJE, van de Laar FA, Bohnen AM. Development and Validation of Search Filters to Identify Articles on Family Medicine in Online Medical Databases. Ann Fam Med. 2015;13(4):364-366.

25. Cameron BJ, Bazemore AW, Morley CP. Lost in Translation: NIH Funding for Family Medicine Research Remains Limited. J Am Board Fam Med. 2016;29(5):528-530.

26. Campos-Outcalt D, Senf J. Family medicine research funding. Fam Med. 1999;31(10):709712 .

27. Lucan SC, Phillips RL Jr, Bazemore AW. Off the roadmap? Family medicine's grant funding and committee representation at NIH. Ann Fam Med. 2008;6(6):534-542.

28. Cameron BJ, Bazemore AW, Morley CP. Federal research funding for family medicine: highly concentrated, with decreasing new investigator awards. J Am Board Fam Med. 2016; SeptOct;29(5)531-532.
29. Merenstein J, Rao G, D’Amico F. Clinical research in family medicine: quantity and quality of published articles. Fam Med. 2003;35(4):284288.

30. Mainous AG III, Hueston WJ, Ye X, Bazell C. A comparison of family medicine research in research intense and less intense institutions. Arch Fam Med. 2000;9(10):1100-1104.

31. Seehusen DA, Mainous AG III, Chessman AW. Creating a Centralized Infrastructure to Facilitate Medical Education Research. Ann Fam Med. 2018;16(3):257-260.

32. Bland CJ, Ruffin MT IV. Characteristics of a productive research environment: literature review. Acad Med. 1992;67(6):385-397.

33. Bland CJ, Center BA, Finstad DA, Risbey KR, Staples JGA. A theoretical, practical, predictive model of faculty and department research productivity. Acad Med. 2005;80(3):225-237.

34. Longo DR. Research capacity building in family medicine: the impact of the grant generating project. Ann Fam Med. 2009;7(6):568-569.

35. Campbell JD, Longo DR. Building research capacity in family medicine: evaluation of the Grant Generating Project. J Fam Pract. 2002;51(7):593.

36. Steiner JF, Lanphear BP, Curtis P, Vu KO. The training and career paths of fellows in the National Research Service Award (NRSA) Program for Research in Primary Medical Care. Acad Med. 2002;77(7):712-718.

37. Doubeni CA, Davis A, Benson JL, Ewigman B. Committee on behalf of the ARD. A Physician scientist pathway in family medicine residency training programs. Ann Fam Med. 2017;15(6):589-590.

38. Lawson PJ, Smith S, Mason MJ, et al. Creating a culture of inquiry in family medicine. Fam Med. 2014;46(7):515-521.

39. Rabinowitz HK, Becker JA, Gregory ND, Wender RC. NIH funding in family medicine: an analysis of 2003 awards. Ann Fam Med. 2006;4(5):437-442.

40. Lucan SC, Barg FK, Bazemore AW, Phillips RL Jr. Family medicine, the NIH, and the medicalresearch roadmap: perspectives from inside the NIH. Fam Med. 2009;41(3):188-196.

41. Lucan SC, Bazemore AW, Phillips RL Jr, Xierali I, Petterson SM, Teevan B. Greater family medicine presence at NIH can improve research relevance and reach. Am Fam Physician. 2010;81(10):1213.

42. Lucan SC, Bazemore AW, Xierali I, Phillips RL Jr, Petterson SM, Teevan B. Greater NIH investment in family medicine would help both achieve their missions. Am Fam Physician. 2010;81(6):704.

43. Newton W, Arndt JE. Learning from history: the legacy of Title VII in academic family medicine. Acad Med. 2008;83(11):1030-1038.

44. Boyer EL. Scholarship Reconsidered: Priorities of the Professoriate. Princeton, NJ: The Carnegie Foundation for the Advancement of Teaching; 1990. 